\title{
ANALISIS PERHITUNGAN PEMOTONGAN DAN PELAPORAN PAJAK PENGHASILAN ATAS PEMBELIAN BAHAN BAKU TERHADAP PEDAGANG PENGUMPUL PADA PT. DELTA PASIFIC INDOTUNA
}

\author{
Nabilah Nur Risfananda Amin ${ }^{1}$, Inggriani Elim², Natalia Y.T.Gerungai ${ }^{3}$ \\ 1,2,3 Jurusan Akuntansi, Fakultas Ekonomi dan Bisnis, Universitas Sam Ratulangi, Jl. Kampus Bahu, Manado \\ 95115, Indonesia \\ E-mail: nabilah.nandaamin@gmail.com
}

\begin{abstract}
Clause 22 income tax which is deducted/collected by the collector is one of the sources of inland revenue (state income), which is deducted by certain agencies/companies appointed by the state to deduct PPh 22, and also the case with PT. The Pacific Delta Indotuna has been appointed by the government as the cutter/collector of clause PPh 22 from the collector as a supplier of raw materials for the fish canning industry. This study aims to analyze the role of business entity (PT Delta Pacific Indotuna) in calculating the tax deduction and reporting of clause PPh 22 that it is in accordance with the Income Tax Law and its implementation regulations. The research method that used is descriptive qualitative approach. The technique of data collecting uses direct surveys, interviews and documentation. Based on the results of the research conducted, it shows that the calculation of withholding of clause Income Tax 22 to the collector and its reporting is in accordance with Minister of Finance Regulation No.34/PMK.010/2017, concerning collection of income tax clause 22 with respect to payment for the delivery of goods and activities in the field of import or business activities in other fields.
\end{abstract}

Keywords: clause 22 about income tax; analysis of tax deduction calculation; reporting analysis; minister of finance regulation; collector

\section{PENDAHULUAN}

Pajak merupakan salah satu sumber utama penerimaan negara yang memiliki peranan sangat penting dalam menopang pembiayaan pembangunan nasional dan juga dapat mencerminkan kemandirian ekonomi suatu bangsa. Di Indonesia,penerimaan negara dari sektor pajak, adalah untuk membiayai pengeluaran pembangunan, dan disisi lain juga sebagai upaya untuk meningkatkan kesejahteraan dan sumber daya manusia dalam segala bidang. Penerimaan negara dari pajak merupakan salah satu sumber penerimaan negara yang telah telah dianggarkan oleh pemerintah dalam anggaran pendapatan dan belanja negara (APBN) untuk suatu periode tahun tertentu.

Salah satu jenis pajak di Indonesia yang cukup potensial untuk ikut membiayai kepentingan negara adalah Pajak Penghasilan $(\mathrm{PPh})$, yaitu pajak negara yang dikenakan terhadap setiap tambahan kemampuan ekonomis yang diterima atau diperoleh wajib pajak, baik yang berasal dari Indonesia maupun dari luar Indonesia, yang dapat dipakai untuk konsumsi atau untuk menambah kekayaan Wajib Pajak yang bersangkutan. Di Indonesia pajak penghasilan diatur dalam UU No.7 tahun 1983 tentang pajak penghasilan dan telah mengalami beberapa kali perubahan dan sampai dengan perubahan keempat yaitu dengan UU No. 36 tahun 2008 tentang perubahan keempat atas UU No.7 tahun 1983 tentang pajak penghasilan, disertai dengan beberapa peraturan pelaksanaannya. Berbagai jenis -jenis pajak penghasilan di Indonesia sebagaimana yang diketahui antara lain adalah Pajak Penghasilan Pasal 21 (PPh Pasal 21), Pajak Penghasilan Pasal 22 (PPh Pasal 22), Pajak Penghasilan Pasal 
23 (PPh Pasal 23), Pajak Penghasilan Pasal 25 (PPh Pasal 25), Pajak Penghasilan Pasal 26 (PPh Pasal 26), dan Pajak Penghasilan Pasal 29 (PPh Pasal 29).

Beberapa jenis pajak penghasilan tersebut, salah satunya adalah PPh Pasal 22 yang merupakan salah satu jenis pajak yang pelunasannya dalam tahun berjalan dipotong atau dipungut oleh pihak ketiga. Sebagai pemotong atau pemungut pajak, maka pihak ketiga tersebut dalam tahun berjalan mempunyai kewajiban untuk memotong atau memungut, menyetor, dan melaporkan pajak yang terutang setiap bulan atau pada masa pajak tersebut. Tujuan pengenaan Pajak Penghasilan Pasal 22 adalah untuk menjaring pajak penghasilan, memperluas daya jangkau dari kebijaksanaan pajak penghasilan, untuk mencegah atau mengurangi keinginan wajib pajak dalam melakukan manipulasi atas nilai peredaran usaha, yang pada akhirnya akan mendorong wajib pajak untuk melaksanakan kewajiban pajaknya dengan baik. Pemotong atau pemungut pajak penghasilan di Indonesia, diatur dalam UU No.7 tahun 1983 tentang Pajak Penghasilan dengan beberapa kali perubahan sampai perubahan keempat yaitu dengan UU No. 36 tahun 2008, menyebutkan bahwa Menteri Keuangan dapat menetapkan pemungut atau pemotong Pajak Penghasilan Pasal $22(\mathrm{PPh}$ Pasal 22) kepada: (1) Bendahara pemerintah untuk memungut pajak sehubungan dengan pembayaran atas penyerahan barang; dan (2) Badan-badan tertentu untuk memungut pajak dari wajib pajak yang melakukan kegiatan dibidang impor atau kegiatan usaha di bidang lain.

Berdasarkan kewenangan yang diberikan undang-undang tersebut maka Menteri Keuangan telah menetapkan badan-badan tertentu sebagai pemungut pajak penghasilan sebagaimana yang dituangkan dalam keputusan Menteri Keuangan No. 154/PMK.03/2010 yang telah mengalami beberapa kali perubahan, dan terakhir dengan peraturan menteri keuangan No. 34/PMK.010/2017 tentang pemungutan pajak penghasilan pasal 22 sehubungan dengan pembayaran atas penyerahan barang dan kegiatan di bidang impor atau kegiatan usaha di bidang lain. Dalam peraturan Menteri Keuangan tersebut, salah satu yang ditetapkan sebagai pemotong atau pemungut pajak penghasilan pasal 22 adalah industri dan eksportir yang bergerak dalam sektor perhutanan, perkebunan, pertanian, dan perikanan, yang melakukan pembelian bahan-bahan untuk keperluan industri atau ekspor mereka dari pedagang pengumpul.

Demikian halnya dengan PT. Delta Pasific Indotuna sebagai salah satu perusahaan yang bergerak di bidang industri pengalengan ikan yang berlokasi di Desa Girian Bawah Kecamatan Girian Kota Bitung Sulawesi Utara, yang dalam operasionalnya tidak memiliki armada penangkapan ikan sendiri, tentunya untuk memperoleh bahan baku ikan sebagai keperluan industrinya, harus bekerjasama dengan perusahaan dan pedagang pengumpul bahan baku ikan untuk kelancaran proses produksinya. Dalam hal ini tentunya PT. Delta Pasific Indotuna, harus aktif berperan dan tidak dapat terlepas dari sebagai pemotong Pajak Penghasilan pasal 22 (PPh Pasal 22) atas pembelian bahan baku ikan pada pedagang pengumpul yang memiliki NPWP dan pedagang pengumpul yang tidak memiliki NPWP, sebagaimana yang ditentukan dalam Perundang-undangan perpajakan di Indonesia.

\section{TINJAUAN PUSTAKA}

Konsep Akuntansi. Akuntansi adalah merupakan proses pengidentifikasian, pengukuran, pencatatan, penggolongan, dan pengikhtisaran serta pelaporan informasi keuangan dalam ukuran moneter (uang) dalam suatu perusahaan atau organisasi yang ditujukan kepada pihak-pihak yang berkepentingan dalam rangka pengambilan keputusan. (Effendi, 2013:1). Akuntansi merupakan pengukuran, penjabaran, atau memberikan kepastian mengenai informasi dan pengambilan keputusan untuk aktivitas keuangan (Sipayung dan Gamaliel, 2018).

Konsep Akuntansi Pajak. Akuntansi Pajak adalah suatu proses pencatatan, penggolongan dan pengikhtisaran suatu transaksi keuangan kaitannya dengan kewajiban 
perpajakan dan diakhiri dengan pembuatan laporan keuangan fiskal sesuai dengan ketentuan dan peraturan perpajakan yang terkait sebagai dasar pembuatan Surat Pemberitahuan Tahunan (Bala, Saerang, dan Elim, 2018). Akuntansi perpajakan adalah akuntansi yang dalam penerapannya menggunakan perhitungan perpajakan dan mengacu pada peraturan dan perundang-undang perpajakan beserta pelaksanaanya disamping Prinsip dan Standar Akuntansi Keuangan (Letlora, Tinangon, dan Kalangi, 2014). Pajak adalah iuran rakyat kepada kas negara berdasarkan undangundang (yang dapat dipaksakan) dengan tidak mendapat jasa timbal balik (kontra prestasi), yang langsung dapat ditunjuk dan dapat digunakan untuk membayar pengeluaran umum (Tambingon, 2018).

Konsep Pajak Penghasilan. Berdasarkan UU No. 7 tahun 1983 tentang pajak penghasilan yang telah mengalami beberapa kali perubahan, sampai dengan perubahan keempat yaitu dengan UU No. 36 tahun 2008, bahwa pajak penghasilan merupakan : (1) Pajak yang dipungut oleh bendaharawan pemerintah, instansi atau lembaga pemerintah, dan lembaga-lembaga negara lainnya berkenaan dengan pembayaran atas penyerahan barang; dan (2) Badan badan tertentu yang berkenaan dengan kegiatan di bidang impor atau kegiatan di bidang lain. Pajak Penghasilan (PPh) adalah pajak yang dikenakan terhadap subjek Pajak atas penghasilan yang diterima atau diperolehnya dalam satu tahun pajak (Resmi, 2014; Tinangon, Saerang, dan Elim, 2015). Undang-undang pajak penghasilan telah menetapkan sistem pemungutan pajak penghasilan secara self assessment, dimana wajib pajak diberi kepercayaan dan tanggung jawab penuh dari pemerintah untuk menghitung, membayar dan melaporkan sendiri jumlah pajak yang terhutang.Dengan sistem ini pemerintah berharap agar pelaksanaan pemungutan pajak penghasilan dapat berjalan dengan lebih mudah dan lancar (Kesek, dan Karamoy, 2013).

Konsep PPh Pasal 22. Pajak Penghasilan Pasal 22 (PPh Pasal 22), adalah pajak penghasilan yang dipungut oleh bendaharawan pemerintah dan lembaga-lembaga negara lainnya berkenan dengan pembayaran atas penyerahan barang dan badan- badan tertentu baik badan pemerintah maupun swasta berkenan dengan kegiatan di bidang impor atau kegiatan usaha di bidang lainnya.

Konsep tarif PPh Pasal 22 pedagang pengumpul. Berdasarkan Peraturan Menteri Keuangan No. 34/PMK.010/2017 tentang pemungutan pajak penghasilan pasal 22 sehubungan dengan pembayaran atas penyerahan barang dan kegiatan di bidang impor atau kegiatan usaha di bidang lain, yang merupakan perubahan atas Peraturan Menteri Keuangan Nomor 16/PMK.010/2016, bahwa besarnya potongan atau pungutan pajak penghasilan pasal 22 atas pembelian bahan-bahan berupa hasil kehutanan, perkebunan, pertanian, peternakan, dan perikanan yang belum melalui proses industri manufaktur oleh badan usaha industri atau eksportir sebesar 0,25\% dari harga pembelian tidak termasuk Pajak Pertambahan Nilai (PPN). Apabila pemungutan diterapkan atas Wajib Pajak (WP) yang tidak memiliki Nomor Pokok Wajib Pajak (NPWP), maka tarif yang akan dikenakan adalah lebih tinggi $100 \%$ dari pada tarif normal yang ditetapkan atau 0,50\% x Harga Pembelian (tidak termasuk PPN).

Pelaporan PPh Pasal 22 oleh Badan Tertentu. Menurut UU Nomor 33 Tahun 2004 tentang Perimbangan Keuangan pasal 1 angka 18 menyatakan bahwa pendapatan asli daerah adalah pendapatan yang diperoleh daerah yang dipungut berdasarkan peraturan daerah sesuai dengan peraturan undang - undang.

Pelaporan PPh Pasal 22 oleh Badan Tertentu. Penyetoran Pajak Penghasilan Pasal 22 (PPh Pasal 22) dilakukan ke kantor kas negara, melalui kantor pos dan giro, serta bank pemerintah yang ditunjuk menggunakan Surat Setoran Pajak (SSP) yang berlaku sebagai Bukti Pemungutan Pajak. Pemungut atau pemotong PPh Pasal 22 dalam hal ini badan tertentu eksportir atau industri wajib melaporkan hasil pemotongan atau pemungutannya dengan menggunakan SPT Masa PPh Pasal 22 ke kantor pelayanan pajak. SPT Masa Pasal 22 merupakan sarana bagi badan tertentu eksportir atau industri sebagai pemungut atau 
pemotong PPh Pasal 22 untuk melaporkan pembayaran atas pemungutan PPh Pasal 22 yang menjadi kewajibannya.

\section{METODE PENELITIAN}

\subsection{Jenis dan sumber data}

Jenis data. Jenis penelitian yang digunakan penulis adalah penelitian kualitatif dengan pendekatan deskriptif , karena tujuan dari penelitian ini untuk mengeksplorasi dan memperoleh gambaran situasi yang diteliti secara luas dan mendalam, khususnya tentang Pemotongan dan Pelaporan Pajak Penghasilan Pasal 22 terhadap pedagang pengumpul pada PT. Delta Pasific Indotuna.

Sumber data. Sumber data yang digunakan dalam penelitian ini adalah data primer yaitu melakukan penelitian langsung ke tempat penelitian untuk mendapatkan data-data yang berhubungan dengan masalah yang akan diteliti.

\subsection{Metode analisis}

Metode yang digunakan dalam penelitian ini adalah metode penelitian lapangan, dengan menggunakan beberapa cara:

1. Wawancara, peneliti sudah mempersiapkan sejumlah pertanyaan untuk ditanyakan kepada karyawan bagian perpajakan PT. Delta Pasific Indotuna. Wawancara ini dilakukan untuk mengetahui bagaimana perhitungan Pemotongan dan Pelaporan PPh Pasal 22 terhadap pedagang pengumpul.

2. Dokumentasi, peneliti memperoleh beberapa rekap data Pemotongan dan Pelaporan $\mathrm{PPh}$ Pasal 22 terhadap pedagang pengumpul tahun 2018.

Proses Analisis yang dilakukan dalam penelitian ini, yaitu :

1. Tahap awal, penulis mengambil data dari PT.Delta Pasific Indotuna agar dapat memahami kondisi dari perusahaan tersebut khususnya tentang perpajakan.

2. Selanjutnya penulis melakukan analisis terhadap perhitungan Pajak Penghasilan yang dilakukan PT.Delta Pasific Indotuna untuk melihat apakah perhitungannya sudah sesuai dengan peraturan yang berlaku yaitu UU No. 36 tahun 2008 dan Peraturan Menteri keuangan No. 34/PMK.010/2017.

3. Setelah menghitung PPh Pasal 22 terhadap pedagang pengumpul yang memliki NPWP dan pedagang pengumpul yang tidak memiliki NPWP, kemudian penulis mengnalisis Pelaporan PPh pasal 22 di PT. Delta Pasific Indotuna.

4. Selanjutnya penulis membuat kesimpulan dari analisis yang sudah dilaksanakan pada beberapa tahap sebelumnya.

5. Dan tahap terakhir dalam proses penelitian ini yaitu memberi saran apabila menemukan sesuatu yang harus dibetulkan oleh PT.Delta Pasific Indotuna, agar supaya menjadi lebih baik dari sebelumnya.

\section{HASIL ANALISIS DAN PEMBAHASAN}

\subsection{Hasil analisis}

Pembangunan pabrik PT. Delta Pasific Indotuna, dimulai sejak akhir bulan Januari 2006, yaitu sejak di perolehnya izin mendirikan bangunan (IMB) dari dinas tata kota,kota Bitung atas nama Walikota Bitung NO.II/IIB tahun 2006 pada tanggal 24 Januari 2006. Pembangunan pabrik dengan segala fasilitasnya membutuhkan waktu sekitar sebelas bulan, dan pada awal Desember tahun 2006 dilakukan uji coba produksi (trial production), sedangkan untuk produksi komersial dimulai pada bulan Januari 2007. Sejak didirikan, PT. Delta Pasific Indotuna telah memiliki 4 unit produksi (plant) yaitu: unit pengalengan ikan (cannery) kapasitas $50 \mathrm{kn}$ bahan baku ikan perhari, pabrik tepung ikan (rendering plant), pabrik es (ice plant), dan unit pabrik kaleng (can making). Pada bulan Juni 2007 (enam bulan 
beroperasi) kapasitas produksi perhari yang telah dicapai, masing-masing sebesar $15 \mathrm{MT}$ untuk unit pabrik es serta 3,5 MT untuk pabrik kaleng.

Pelaksanaan Pajak Penghasilan Pasal 22 terhadap pedagang pengumpul pada PT. Delta Pasific Indotuna. Dasar hukum pajak penghasilan (PPh) Pasal 22: (1) Pasal 22 undang-undang Nomor 7 Tahun 1983 tentang pajak penghasilan sebagaimana telah beberapa kali diubah dan terakhir dengan undang-undang nomor 36 tahun 2008; (2) Peraturan Menteri Keuangan nomor 34/PMK.010/2017 tentang pemungutan pajak penghasilan Pasal 22 sehubungan dengan pembayaran atas penyerahan barang dan kegiatan di bidang impor atau kegiatan usaha di bidang lain, yang merupakan perubahan atas Peraturan Menteri Keuangan nomor 16/PMK.010/2016; dan (3) Perhitungan PPh Pasal 22 terhadap pedagang pengumpul. Dalam melaksanakan perhitungan pemotongan PPh Pasal 22 terhadap pedagang pengumpul yang memiliki NPWP dan terhadap pedagang pengumpul yang tidak memiliki NPWP, pemotongannya berdasarkan rumus berikut :

Memiliki NPWP $\quad$ : PPh Pasal $22=$ Tarif $0.25 \%$ x Harga Beli

Tidak Memiliki NPWP : PPh Pasal $22=$ Tarif $0.25 \%$ x Harga Beli

Perhitungan pemotongan PPh Pasal 22 terhadap pedagang pengumpul yang memiliki NPWP. Pada tanggal 08 Juni tahun 2018, PT. Delta Pasific Indotuna melakukan pembelian ke salah satu pedagang pengumpul yang memiliki NPWP yaitu PT. Sari Usaha Mandiri, dengan dasar nota timbang yang diserahkan ke juru bayar sebagai berikut :

$\begin{array}{ll}\text { Harga beli bahan baku ikan } & =\text { Rp. 222.961.750,- } \\ \text { Perhitungan potongan PPh pasal } 22 & =\text { Rp. } 222.961 .750 \times 0.25 \% \\ \text { Potongan PPh pasal } 22 & =\text { Rp. 557.404,-- }\end{array}$

Harga beli yang dibayarkan ke pedagang pengumpul adalah :

Rp. 222.961.750 - Rp. 557.404= Rp. 222.404.346,-

Perhitungan pemotongan PPh Pasal 22 terhadap pedagang pengumpul yang tidak memiliki NPWP. Pada tanggal 10 Juni 2018 PT. Delta Pasific Indotuna melakukan pembelian ke salah satu pedagang pengumpul yang tidak memiliki NPWP yaitu pada nama pribadi (Rendi), dengan dasar nota timbang yang diserahkan ke juru bayar sebagai berikut :

Harga beli bahan baku ikan= = Rp. 50.999.900,-

Perhitungan potongan PPh pasal $22=\mathrm{Rp} .50 .999 .900 \times 0.5 \%$

Potongan PPh pasal $22=$ Rp. 255.000,-

Harga beli yang dibayarkan ke Pedagang pengumpul adalah :

Rp. 50.999.900 - Rp. Rp. $255.000=$ Rp. 50.744.900,-

Berikut ini adalah data Pemotongan PPh Pasal 22 atas pembelian bahan baku terhadap pedagang pengumpul dilakukan oleh PT.Delta Pasific Indotuna selama tahun 2018 :

Tabel 1. Data pemotongan PPh Pasal 22 Tahun 2018 terhadap pedagang pengumpul

\begin{tabular}{|c|c|c|}
\hline Masa Pajak & Nilai Objek Pajak (Rp) & PPh Pasal 22 (Rp) \\
\hline Januari & $8.950 .940 .000,-$ & $28.503 .850,-$ \\
\hline Februari & $9.081 .000 .264,-$ & 25.903.376,- \\
\hline Maret & 10.600.896.120,- & $33.378 .865,-$ \\
\hline April & 10.091.507.000,- & $33.331 .185,-$ \\
\hline Mei & 11.420.510.000,- & $37.451 .875,-$ \\
\hline Juni & 11.951.826.195,- & 39.505.380,- \\
\hline Juli & 11.951.826.195,- & $34.635 .550,-$ \\
\hline Agustus & 11.531.839.000,- & $35.232 .033,-$ \\
\hline September & 12.138.115.365,- & $37.540 .413,-$ \\
\hline Oktober & 10.380546.500,- & $32.776 .881,-$ \\
\hline November & 10.056.040.650,- & 29.591.078,- \\
\hline Desember & 10.321.345.854,- & $31.880 .040,-$ \\
\hline Total & 127.735.647.072,- & 399.721.654,- \\
\hline
\end{tabular}


Tabel 1 menunjukkan bahwa terjadi pembelian bahan baku ikan oleh PT. Delta Pasific Indotuna terhadap pedagang pengumpul yang memiliki NPWP dan yang tidak memiliki NPWP selama tahun 2018, dengan nilai objek pajak sebesar Rp. 127.735.647.072 dan jumlah pemotongan Pajak Penghasilan Pasal 22, sebesar Rp. 399.721.654. Tabel 2 menunjukkan perhitungan pemotongan $\mathrm{PPh}$ pasal 22 terhadap pedagang pengumpul yang memiliki NPWP dengan tarif 0,25\% pada tahun 2018 oleh PT. Delta Pasific Indotuna.

Tabel 2. Data Pemotongan PPh Pasal 22 Tahun 2018 terhadap pedagang pengumpul yang memiliki NPWP

\begin{tabular}{|c|c|c|}
\hline Masa Pajak & Nilai Objek Pajak (Rp) & PPh Pasal 22 (Rp) \\
\hline Januari & $6,500,340,000,-$ & $16,250,850,-$ \\
\hline Februari & $7,800,650,000,-$ & $19,501,625,-$ \\
\hline Maret & $7,850,246,120,-$ & $19,625,615,-$ \\
\hline April & $6,850,540,000,-$ & $17,126,350,-$ \\
\hline Mei & $7,860,270,000,-$ & $19,650,675,-$ \\
\hline Juni & $8,101,500,000,-$ & $20,253,750,-$ \\
\hline Juli & $8,560,740,000,-$ & $21,401,850,-$ \\
\hline Agustus & $8,970,865,000,-$ & $22,427,162,-$ \\
\hline September & $9,270,865,200,-$ & $23,177,163,-$ \\
\hline Oktober & $7,650,290,500,-$ & $19,125,726,-$ \\
\hline November & $8,275,650,000,-$ & $20,689,125,-$ \\
\hline Desember & $7,890,675,600,-$ & $19,726,689,-$ \\
\hline Total & $95,582,632,420,-$ & 238,956,581,- \\
\hline
\end{tabular}

Tabel 3 menunjukkan perhitungan pemotongan $\mathrm{PPh}$ Pasal 22 terhadap pedagang pengumpul yang tidak memiliki NPWP dengan tarif 0,5\% pada tahun 2018 oleh PT. Delta Pasific Indotuna :

Tabel 3. Pemotongan PPh tahun 2018 pada pedagang pengumpul yang tidak memiliki NPWP

\begin{tabular}{|c|c|c|}
\hline Masa Pajak & Nilai Objek Pajak (Rp) & PPh Pasal 22 (Rp) \\
\hline Januari & $2,450,600,000,-$ & $12.253 .000,-$ \\
\hline Februari & $1,280,350,264,-$ & $6.401 .751,-$ \\
\hline Maret & $2,750,650,000,-$ & 13.753.250,- \\
\hline April & $3,240,967,000,-$ & 16.204.835,- \\
\hline Mei & $3,560,240,000,-$ & 17.801200,- \\
\hline Juni & $3,850,326,195,-$ & 19.251.630,- \\
\hline Juli & $2,650,340,124,-$ & 13.251.700,- \\
\hline Agustus & $2,560,974,000,-$ & 12.804.870,- \\
\hline September & $2,867,250,165,-$ & 14.336.250,- \\
\hline Oktober & $2,730,256,000,-$ & 13.651.280,- \\
\hline November & $1,780,390,650,-$ & 8.901.953,- \\
\hline Desember & $2,430,670,254,-$ & 12.153.351,- \\
\hline Total & $32,153,014,652,-$ & $160.765,073,-$ \\
\hline
\end{tabular}

Data Diolah,2019

Berikut adalah total dari nilai objek pajak dan total Pemotongan PPh Pasal 22 terhadap pedagang pengumpul yang memiliki NPWP dan tidak memiliki NPWP pada tahun 2018 oleh PT. Delta Pasific Indotuna :

Tabel 4. Total Nilai Objek Pajak dan Pemotongan PPh Pasal 22 Tahun 2018

\begin{tabular}{ccc}
\hline Wajib Pajak & Nilai Objek Pajak & Pemotongan PPh Pasal 22 \\
\hline Ber-NPWP & $95,582,632,420,-$ & $238,956,581,-$ \\
Tidak Ber-NPWP & $32,153,014,652,-$ & $160.765,073,-$ \\
\hline Total & $\mathbf{1 2 7 . 7 3 5 . 6 4 7 . 0 7 2 , -}$ & $\mathbf{3 9 9 . 7 2 1 . 6 5 4 , -}$ \\
\hline
\end{tabular}

Sumber: Data Diolah,2019 
Tabel 4 menunjukan selama tahun 2018 PT. Delta Pasific Indotuna telah melakukan pembelian bahan baku ikan terhadap pedagang pengumpul yang memiliki NPWP dan terhadap pedagang pengumpul yang tidak memiliki NPWP dengan nilai objek pajak Rp.127.735.647.072,- dan Pemotongan PPh Pasal 22 sebesar Rp. 399.721.654,- . Adapun total nilai tersebut sesuai dengan data perhitungan dari PT. Delta Pasific Indotuna yang ada pada tabel 1. Dengan demikian Pemotongan PPh Pasal 22 terhadap pedagang yang dilakukan oleh PT. Delta Pasific Indotuna telah sesuai dengan peraturan yang berlaku.

Pelaporan pemotongan PPh pasal 22 oleh PT. Delta Pasific Indotuna. Pajak Penghasilan Pasal 22 yang dipotong oleh PT. Delta Pasific Indotuna terhadap pedagang pengumpul, pelaporannya dilakukan di Kantor Pelayanan Pajak (KPP) Pratama Bitung. Sesuai dengan Peraturan Menteri Keuangan No.243/ PMK.03/2014, tentang Surat Pemberitahuan (SPT) Pasal 10 ayat (5),bahwa Wajib Pajak badan tertentu sebagai Pemungut Pajak, wajib melaporkan PPh Pasal 22 yang dipungut dengan menyampaikan SPT Masa PPh Pasal 22 paling lama 20 (dua puluh) hari setelah Masa Pajak berakhir. Berikut adalah penjelasan mengenai Pelaporan SPT Masa PPh Pasal 22 yang dilakukan oleh PT.Delta Pasific Indotuna, apakah telah sesuai dengan peraturan perundang - undangan yang berlaku :

Tabel 5. Pelaporan PPh Pasal 22 oleh PT. Delta Pasific Indotuna Tahun 2018

\begin{tabular}{lccc}
\hline \multicolumn{1}{c}{ Masa Pajak } & $\begin{array}{c}\text { Jumlah Pemotongan } \\
\text { PPh Pasal 22 }(\mathbf{R p})\end{array}$ & \multicolumn{1}{c}{ Tanggal Lapor } & $\begin{array}{c}\text { Keterangan } \\
\text { (Kesesuaian dengan } \\
\text { PMK/243.03/2014) }\end{array}$ \\
\hline Januari & $28.503 .850,-$ & 19 Februari 2018 & Sudah Sesuai \\
Februari & $25.903 .376,-$ & 20 Maret 2018 & Sudah Sesuai \\
Maret & $33.378 .865,-$ & 19 April 2018 & Sudah Sesuai \\
April & $33.331 .185,-$ & 21 Mei 2018 & Sudah Sesuai \\
Mei & $37.451 .875,-$ & 20 Juni 2018 & Sudah Sesuai \\
Juni & $39.505 .380,-$ & 19 Juli 2018 & Sudah Sesuai \\
Juli & $34.635 .550,-$ & 20 Agustus 2018 & Sudah Sesuai \\
Agstus & $35.232 .033,-$ & 20 September 2018 & Sudah Sesuai \\
September & $37.540 .413,-$ & 22 Oktober 2018 & Sudah Sesuai \\
Oktober & $32.776 .881,-$ & 21 November 2018 & Sudah Sesuai \\
November & $29.591 .078,-$ & 20 Desember 2018 & Sudah Sesuai \\
Desember & $31.880 .040,-$ & 21 Januari 2019 & Sudah Sesuai \\
\hline
\end{tabular}

Sumber: Data Diolah,2019

Berdasarkan Tabel 5 Pelaporan Pajak Penghasilan Pasal 22 yang dilakukan oleh PT. Delta Pasific Indotuna pada Kantor Pelayanan Pajak (KPP) Pratama Bitung, didasarkan pada waktu yang telah ditetapkan yaitu paling lambat 20 (dua puluh) hari setelah masa pajak berakhir. Tapi pada kenyataanya pelaporan dapat juga terjadi melebihi dari waktu tersebut, dikarenakan beberapa hal misalnya batas waktu Pelaporan bertepatan dengan hari libur, dan hal - hal lain.

\subsection{Pembahasan}

Sebagai badan tertentu atau perusahaan yang ditunjuk sebagai pemotong $\mathrm{PPh}$ pasal 22, maka PT. Delta Pasific Indotuna, pada setiap transaksi pembelian bahan baku ikan, wajib membuat bukti potong $\mathrm{PPh}$ pasal 22. Bukti potong ini sebagai dasat telah terjadinya pemotongan $\mathrm{PPh}$ pasal 22 terhadap pedagang pengumpul untuk itu satu rangkap bukti ini diserahkan ke pedagang pengumpul. Berdasarkan bukti potong tersebut sebagai dokumen pemotongan yang terjadi pada setiap transasksi, maka PT. Delta Pasific Indotuna juga harus merekap dalam satu dokumen untuk seluruh transasksi atau pemotongan PPh pasal 22 yang berlangsung pada satu masa pajak (setiap bulan) tersebut, yaitu melalui formulir daftar pemungutan $\mathrm{PPh}$ pasal 22.

Berdasarkan penelitian yang telah dilakukan oleh penulis dapat dilihat dan diamati bahwa perhitungan pemotongan PPh pasal 22 yang dilakukan oleh PT. Delta Pasific Indotuna 
terhadap pedagang pengumpul telah sesuai dengan Peraturan Menteri Keuangan No. 34 / PMK.010 / 2017, tentang pemungutan pajak penghasilan pasal 22 sehubungan dengan pembayaran atas penyerahan barang dan kegiatan di bidang impor atau kegiatan usaha di bidang lain, diantara adalah pemotongan PPh Pasal 22 dengan menggunakan tarif $0.25 \%$ terhadap pedagang pengumpul yang memiliki NPWP dan tarif $0.5 \%$ untuk yang yang tidak memiliki NPWP.

Adapun untuk pelaporan pajak penghasilan pasal 22 yang dilakukan oleh PT. Delta Pasific Indotuna pada tahun 2018 telah sesuai walaupun pada kenyatannya pernah terjadi keterlambatan dengan alasan bukan disebabkan kelalaian yang disengaja, akan tetapi lebih pada waktu penyetoran dan pelaporannya terjadi pada hari libur, sehingga waktu tersebut sangatlah kurang cukup karena harus merekap data selama satu bulan dengan ratusan transasksi dan dengan harga bahan baku tidak selalu sama juga pada setiap hari. Keterlambatan penyetoran dan pelaporan bukan berlangsung sampai melewati suatu masa pajak tertentu, tetapi penyetoran dan pelaporan tetap dilakukan pada bulan yang ditentukan hanya melewati tanggal yang ditentukan oleh undang-undang saja.

\section{KESIMPULAN DAN SARAN}

\subsection{Kesimpulan}

Berdasarkan hasil dalam penelitian ini kesimpulannya adalah:

1. Perhitungan pemotongan Pajak Penghasilan pasal 22 (PPh Pasal 22) yang dilakukan oleh PT. Delta Pasific Indotuna sebagai Pemungut atau pemotong terhadap pedagang pengumpul bahan baku ikan, telah sesuai dengan Peraturan Menteri Keuangan No. 34 / PMK.010 / 2017, tentang pemungutan pajak penghasilan pasal 22 sehubungan dengan pembayaran atas penyerahan barang dan kegiatan di bidang impor atau kegiatan usaha di bidang lain.

2. PT. Delta Pasific Indotuna pernah mengalami keterlambatan dalam hal penyetoran dan pelaporan, akan tetapi penyebabnya bukan karena suatu hal yang prinsip, tapi dikarenakan waktu yang ditetapkan bertepatan dengan hari libur, sehingga untuk hal demikian harus membutuhkan waktu ekstra untuk melakukan persiapan sebelum batas waktu penyetoran dan pelaporan.

3. PT. Delta Pasific Indotuna, sebagai salah satu perusahaan yang terdaftar dan telah ditunjuk sebagai pemotong atau pemungut $\mathrm{PPh}$ pasal 22, telah melaksanakan kewajibannya dalam perpajakan yaitu dengan melakukan pemotongan $\mathrm{PPh}$ pasal 22 terhadap pedagang pengumpul, dan melakukan penyetoran melalui bank persepsi (BNI 46 Bitung) dengan fasilitas e-billing (kode billing) dan melaporkan pemotongan dan penyetoran PPh Pasal 22 tersebut ke Kantor Pelayanan Pajak Pratama Bitung.

\subsection{Saran}

Sesuai dengan hasil penelitian yang telah dilakukan penulis pada PT. Delta Pasific Indotuna, maka penulis memberikan saran:

1. PT. Delta Pasific Indotuna harus selalu mengikuti segala perkembangan dan perubahan yang terjadi dalam peraturan perpajakan, karena peraturan dan ketentuan pajak seringkali terjadi perubahan yang berguna untuk mempermudah proses perpajakan di Indonesia, dan memanfaatkan fasilitas penyetoran dan pelaporan secara online sehingga segala sesuatu akan lebih efektif.

2. Untuk menghindari diberlakukannya sanksi administrasi yang dikarenakan terjadi keterlambatan penyetoran dan pelaporan PPh pasal 22, maka pembuatan rekapan daftar bukti pemotongan harus segera dilakukan pada setiap hari, sehingga akan mempermudah pada rekapan satu masa pajak, dan penyetorannya tidak harus menunggu batas waktu akhir yang ditentukan, demikian juga dengan pelaporan tidak harus menunggu batas 
waktu akhir yang ditentukan UU, sehingga masalah keterlambatan penyetoran dan pelaporan dapat diminimalisir.

\section{DAFTAR PUSTAKA}

Azis, A. dan Budiarso, N. (2016). Analisis pemungutan dan pelaporan pajak PPh 22 atas kegiatan impor barang pada Kantor Pelayanan Pengawasan Bea dan Cukai Kota $\begin{array}{llll}\text { Manado. Jurnal } & \text { 753-762. }\end{array}$ https://ejournal.unsrat.ac.id/index.php/emba/article/view/11781

Binsarjono. (2016). Modul Pelatihan Brevet AB. Jakarta: Sulu Prima Target.

Effendi, R. (2013). Accountng Principles Prinsip-prinip Akuntansi Berbasis SAK ETAP. Edisi Revisi. Jakarta: PT. Rajagrafindo Persada.

Bala, G., Saerang, D., \& Elim, I. (2018). Analisis Pajak Pertambahan Nilai dan Pajak Penghasilan Pasal 22 pada PT. Makmur Auto Mandiri. Going Concern : Jurnal Riset Akuntansi, 13(04), 404-411. https://doi.org/10.32400/gc.13.04.21173.2018

Ilmi, Y. (2016). Analisis Pajak Pertambahan Nilai Pada PT. Jen Tsong Indonesia. Skripsi. Fakultas Ekonomi Universitas Islam Negeri (UIN) Maulana Malik Ibrahim. Malang. from http://etheses.uin-malang.ac.id/6625/

Kesek, M., \& Karamoy, H. (2013). Prosedur perhitungan dan pelaporan Pajak Penghasilan (PPH) Pasal 21 atas gaji pegawai pada Pemerintah Kota Bitung. Jurnal Accountability, 2(2), 20-33. https://doi.org/10.32400/ja.3683.2.2.2013.20-33

Letlora, R., Tinangon, J., \& Kalangi, L. (2014). Penerapan Peryataan Standar Akuntansi Keuangan Nomor 46 tentang akuntansi pajak penghasilan dan Undang-Undang Nomor 36 tahun 2008 tentang pajak penghasilan atas pajak penghasilan badan pada PT. Mega Jasakelola. Going Concern: Jurnal Riset Akuntansi, 9(1), 125-136. https://doi.org/10.32400/gc.9.1.25211.2014

Mardiasmo. (2016). Perpajakan. Edisi Terbaru 2016. Yogyakarta: Andi.

Peraturan Direktur Jenderal Pajak No. PER - 31/PJ/2015, Perubahan Ketiga atas Peraturan Direktur Dirjen Pajak No. 57/PJ/2010 tentang Tata Cara dan Prosedure Pemungutan PPh Pasal 22 Sehubungan Dengan Pembayaran atas Penyerahan Barang dan Kegiatan di Bidang Impor atau Kegitan Usaha di Bidang Lain. 5 Agustus 2015. Jakarta. from https://pajak.go.id/id/peraturan-direktur-jenderal-pajak-nomor-31pj2015

Peraturan Menteri Keuangan No. 34/PMK.010/2017. Pemungutan PPh Pasal 22 sehubungan dengan pembayaran atas Penyerahan Barang dan Kegiatan di Bidang Impor atau Kegiatan Usaha di Bidang Lain. Merupakan Perubahan terakhir atas Peraturan Menteri Keuangan Nomor 154/PMK.03/2010. http://www.jdih.kemenkeu.go.id/fullText/2017/34 PMK.010 2017Per.pdf

Resmi, S. (2014). Perpajakan Teori dan Kasus, Buku 1 Edisi 8. Jakarta: Salemba Empat.

Simanjuntak, H. dan Imam, M. (2012). Dimensi ekonomi perpajakan dalam pembangunan ekonomi. Bogor : Penerbit Raih Asa Sukses (Penebar Swadaya Grup).

Sipayung, Y., \& Gamaliel, H. (2018). Ipteks analisis hasil laporan keuangan dan aset Sulawesi Utara. Jurnal Ipteks Akuntansi Bagi Masyarakat, 2(2), 594-597. https://doi.org/10.32400/jiam.2.02.2018.21840

Tambingon, V. (2018). Ipteks pencatatan dan perhitungan Pajak Penghasilan (PPh 21) pada PT. Bank Rakyat Indonesia (Persero) Tbk. Cabang Manado Unit Malalayang. Jurnal Ipteks Akuntansi Bagi Masyarakat, 2(1), 31-37. https://doi.org/10.32400/jiam.2.1.2018.23524

Tinangon, C., Saerang, D., \& Elim, I. (2015). Analisis perhitungan, pencatatan dan pelaporan Pajak Penghasilan Pasal 23 atas pengadaan barang dalam hal ini jasa penyewaan 
barang berat pada PT. William Makmur Perkasa. Jurnal Accountability, 4(1), 26-32. https://doi.org/10.32400/ja.8409.4.1.2015.26-32

Undang-Undang Republik Indonesia No. 36 Tahun 2008, Perubahan keempat atas Undang Undang No. 7 Tahun 1983, tentang Pajak Penghasilan. 23 September 2008. https://www.pajak.go.id/id/undang-undang-nomor-36-tahun-2008 